\title{
Janibacter limosus gen. nov., sp. nov., a New Actinomycete with meso-Diaminopimelic Acid in the Cell Wall
}

\author{
KARIN MARTIN, ${ }^{1 *}$ PETER SCHUMANN, ${ }^{2}$ FREDERICK A. RAINEY,${ }^{3}$ BARBARA SCHUETZE, ${ }^{1}$ \\ AND INGRID GROTH ${ }^{1}$ \\ Hans-Knöll-Institut für Naturstoff-Forschung e.V., ${ }^{1}$ and DSMZ-Deutsche Sammlung von Mikroorganismen und \\ Zellkulturen GmbH, Aussenstelle Jena, ${ }^{2}$ D-07745 Jena, and DSMZ-Deutsche Sammlung von \\ Mikroorganismen und Zellkulturen GmbH, D-38124 Braunschweig, ${ }^{3}$ Germany
}

\begin{abstract}
New gram-positive bacteria were isolated from 1-year-old sludge from a wastewater treatment plant. The isolates are coccoid to rod-shaped, nonmotile aerobes that form neither spores nor mycelia. They are characterized by a peptidoglycan with directly cross-linked meso-diaminopimelic acid (type A1 $\gamma$ ), by the presence of menaquinone MK-8 $\left(\mathrm{H}_{4}\right)$, and by the lack of mycolic acids. The strains have complex fatty acid patterns with $\mathrm{i}-\mathrm{C}_{16: 0}$ and straight-chain saturated and unsaturated fatty acids as major components. The $\mathrm{G}+\mathrm{C}$ content of the DNA is $70 \mathrm{~mol} \%$. The results of chemotaxonomic studies and a $16 \mathrm{~S}$ ribosomal DNA sequence comparison support our proposal to assign these bacteria to a new genus, the genus Janibacter gen. nov.; the type species is Janibacter limosus sp. nov., and the type strain of J. limosus is strain HKI 83 (= DSM 11140).
\end{abstract}

Both spore-forming and asporogenous actinomycetes have been screened during the last few years for useful bioactive compounds $(13,39)$. The asporogenous organisms play important roles in mineralization of environmentally hazardous chemicals, such as polycyclic aromatic hydrocarbons (22), and in biotechnological production of natural products $(23,26,29)$.

To isolate new actinomycetes with new biological activities, we investigated several samples of soil, sludge, and sewage waste. A total of 168 strains were isolated from a 1-year-old sludge sample collected from a wastewater treatment plant. Two of these isolates were found to be markedly different from the other isolates and from previously described genera in their chemotaxonomic and their physiological features. In this paper these two strains are characterized phenotypically and phylogenetically. Below we propose the creation of a new genus, the genus Janibacter gen. nov., with one species, Janibacter limosus sp. nov., for these organisms.

\section{MATERIALS AND METHODS}

Bacterial strains and cultural conditions. Strains $\mathrm{HKI} 83^{\mathrm{T}}(\mathrm{T}=$ type strain) and HKI 84 were isolated from a 1-year-old sludge sample from the wastewater treatment plant near Jena, Thuringia, Germany, by the dilution plate technique on plate count agar (Difco Laboratories, Detroit, Mich.). General laboratory cultivation was performed at $28^{\circ} \mathrm{C}$ on solid rich medium ( $\mathrm{R}$ medium) or in liquid $\mathrm{R}$ medium (43), which contained 1\% (wt/vol) Bacto Peptone (Difco), $0.5 \%$ (wt/vol) yeast extract, $0.5 \%$ (wt/vol) Casamino Acids, $0.2 \%(\mathrm{wt} / \mathrm{vol})$ meat extract, $0.5 \%(\mathrm{wt} / \mathrm{vol})$ malt extract, $0.2 \%(\mathrm{wt} / \mathrm{vol})$ glycerol, $0.1 \%(\mathrm{wt} / \mathrm{vol}) \mathrm{MgSO}_{4}$ $7 \mathrm{H}_{2} \mathrm{O}$, and $0.005 \%$ (wt/vol) Tween $80(\mathrm{pH} \mathrm{7.2)}$. To determine the cellular fatty acids, strains were cultivated for $24 \mathrm{~h}$ in liquid tryptic soy broth (Difco) at $28^{\circ} \mathrm{C}$.

Morphological and physiological characteristics. Colony morphology on $\mathrm{R}$ medium and cell morphology at different ages were determined by stereomicroscopy and phase-contrast microscopy (Olympus, Tokyo, Japan). Nitrate reductase activity, urease activity, indole production, methyl red and Voges-Proskauer reactions, hydrogen sulfide production, and hydrolysis of esculin and Tween 80 were determined as described by Lanyi (25). Acid production from carbohydrates was determined by using the method of Hugh and Leifson (16), as modified by Gledhill and Casida (10). Utilization of organic acids $(2 \% \mathrm{wt} / \mathrm{vol}$; sodium salts) was studied by the method of Gordon and Mihm (12). Decomposition of adenine, hypoxanthine, xanthine, and tyrosine was determined by using the method of Gordon et al. (11). Catalase production and hydrolysis of casein

\footnotetext{
* Corresponding author. Mailing address: Hans-Knöll-Institut für Naturstoff-Forschung e.V., Beutenbergstraße 11, D-07745 Jena, Germany. Phone: 049-3641-656669. Fax: 049-3641-656600. E-mail: kmartin @leutra.imb-jena.de.
}

and starch were determined by the methods of Gledhill and Casida (10). The cytochrome oxidase test was performed by using DrySlide Oxidase Test strips (Difco). The oxygen requirement was determined by using a Generbag Microae incubation system (bioMerieux, Marcy l'Etoile, France). The test to determine hydrolysis of hippurate was performed as described by Cowan and Steel (5). The test to determine decomposition of gelatin was performed by using a modification of the method described by Lanyi (25). A UV-sterilized photographic film strip was immersed in phosphate buffer, which was inoculated with the test strains at a density of $6 \times 10^{8}$ cells per ml (McFarland no. 2 nephelometer standard). After 3 to 7 days of incubation, hydrolysis of the gelatin layer was checked. Sodium chloride tolerance and growth at 28,37 , and $50^{\circ} \mathrm{C}$ were tested on brain heart infusion (BHI) medium (Difco) and R medium. Resistance to antibiotics was tested by placing antibiotic discs (Oxoid, Hampshire, United Kingdom) on agar plates seeded with the test strains.

Cell wall analysis. A cell wall analysis was performed as described previously (14). Purified cell wall preparations were obtained by the method of Schleife and Kandler (34). The amino acids and peptides of cell wall hydrolysates were analyzed by thin-layer chromatography on cellulose plates by using the solvent systems described by Schleifer and Kandler (34). The molar ratios of amino acids were determined by gas chromatography-mass spectrometry of $N$-heptafluorobutyryl amino acid isobutyl esters as described previously (14). The whole-cell sugars were determined by gas chromatography of alditol acetates as described by Saddler et al. (33). The glycolate content of bacterial cells was determined by the colorimetric method of Uchida and Aida (41)

Lipid analysis. The cellular fatty acid methyl esters were determined by gas chromatography by using the method of Stead et al. (38). Menaquinones were extracted as described by Collins et al. (4) and were analyzed by high-performance liquid chromatography (14). Polar lipids were extracted and identified by the method of Minnikin et al. (31). The absence of mycolic acids was shown by thin-layer chromatography as described by Minnikin et al. (30).

Analysis of DNA base composition. DNA was isolated by using a modification of the Marmur method (27). DNA was purified by treatment with proteinase K and was degraded to nucleosides with P1 nuclease and bovine intestinal mucosa alkaline phosphatase as described by Mesbah et al. (28). The nucleosides were separated by reversed-phase high-performance liquid chromatography as described by Tamaoka and Komagata (40). G+C contents were calculated from the ratios of deoxyguanosine and thymidine.

DNA-DNA hybridization. DNA was isolated by chromatography on hydroxyapatite by the procedure of Cashion et al. (1). DNA-DNA hybridization was carried out as described by De Ley et al. (6), with the modifications described by Huss et al. (17), using a Gilford System model 2600 spectrophotometer equipped with a Gilford model $2527-\mathrm{R}$ thermoprogrammer and plotter. Renaturation rates were computed with the TRANSFER.BAS program (18).

$16 S$ rDNA sequence determination and analysis. Genomic DNAs were extracted from the strains investigated in this study and were used for PCR mediated amplification of $16 \mathrm{~S}$ ribosomal DNA (rDNA) as described by Rainey et al. (32). The purified PCR products were directly sequenced by using previously described protocols (32), and the sequence reaction mixtures were electrophoresed by using a model 373A automatic DNA sequencer (Applied Biosystems, Foster City, Calif.). The 16S rDNA sequences were manually aligned with the sequences of previously described members of the order Actinomyce tales. Evolutionary distances were calculated by the method of Jukes and Cantor 

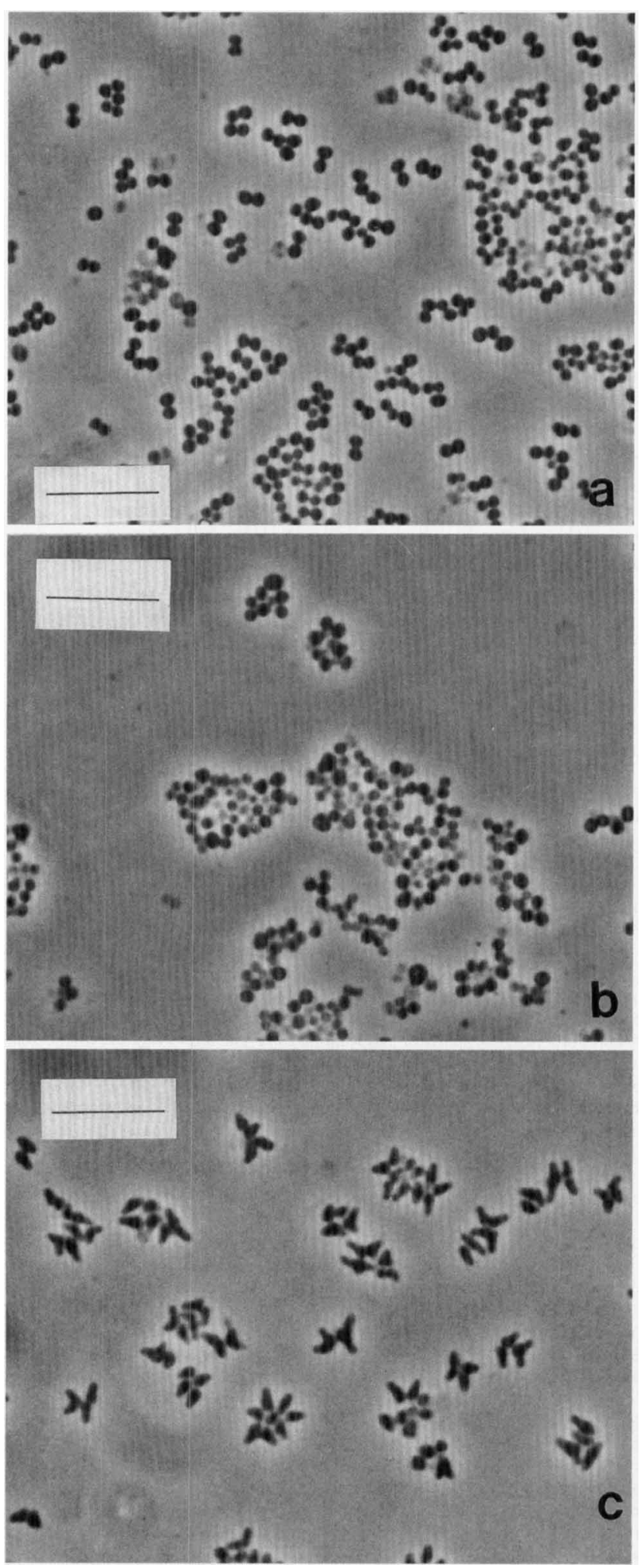

FIG. 1. (a) Micrograph of strain HKI 84 cells grown on solid R medium at $28^{\circ} \mathrm{C}$ for $24 \mathrm{~h}$. Bar $=10 \mu \mathrm{m}$. (b) Micrograph of strain HKI $83^{\mathrm{T}}$ cells grown in liquid $\mathrm{R}$ medium at $28^{\circ} \mathrm{C}$ for $24 \mathrm{~h}$. Bar $=10 \mu \mathrm{m}$. (c) Micrograph of strain $\mathrm{HKI}$ $83^{\mathrm{T}}$ cells grown on an agar slide at $28^{\circ} \mathrm{C}$ for $12 \mathrm{~h}$. Bar $=10 \mu \mathrm{m}$.

(20), and a phylogenetic dendrogram was constructed by using the least-squares method (7).

Nucleotide sequence accession numbers. The $16 \mathrm{~S}$ rDNA sequences determined in this study have been deposited in the EMBL database under the following accession numbers: J. limosus DSM $11140^{\mathrm{T}}$, Y08539; J. limosus DSM 11141, Y08540; and Microsphaera multipartita JCM $9543^{\mathrm{T}}$, Y08541.

\section{RESULTS}

Morphological and cultural characteristics. Cells of strains HKI $83^{\mathrm{T}}$ and HKI 84 are gram-positive and nonmotile and occur singly, in pairs, or occasionally in irregular clumps. While the cells of strain HKI 84 are always coccoid and vary in diameter from 0.4 to $1.1 \mu \mathrm{m}$ (Fig. 1a), the cells of strain HKI $83^{\mathrm{T}}$ differ morphologically during the growth cycle. In liquid strain HKI $83^{\mathrm{T}}$ cultures only coccoid cell are observed, and these cells vary from 0.3 to $1.2 \mu \mathrm{m}$ in diameter (Fig. 1b). After the cells are transferred to agar slides, the coccoid cells give rise to small irregular rods $(0.4$ by $1.2 \mu \mathrm{m})$ (Fig. 1c), but the cells in older cultures are coccoid. Colonies of strain HKI $83^{\mathrm{T}}$ on nutrient agar are white, opaque, and convex with glistening surfaces (Fig. 2a). The colony margins are entire. Colonies of strain HKI 84 on nutrient agar are yellow, opaque, and convex (Fig. 2b). The surfaces are matt, and the colony margins are entire.

Both strains grow aerobically and in presence of $4 \%(\mathrm{wt} / \mathrm{vol})$ sodium chloride in the culture medium. The optimal growth temperature is $28^{\circ} \mathrm{C}$. Growth occurs at $37^{\circ} \mathrm{C}$ on BHI medium but not on $\mathrm{R}$ medium. No growth occurs under anaerobic conditions. Spore formation is not observed.

Physiological characteristics. The physiological properties of isolates HKI $83^{\mathrm{T}}$ and HKI 84 are shown in Table 1 .
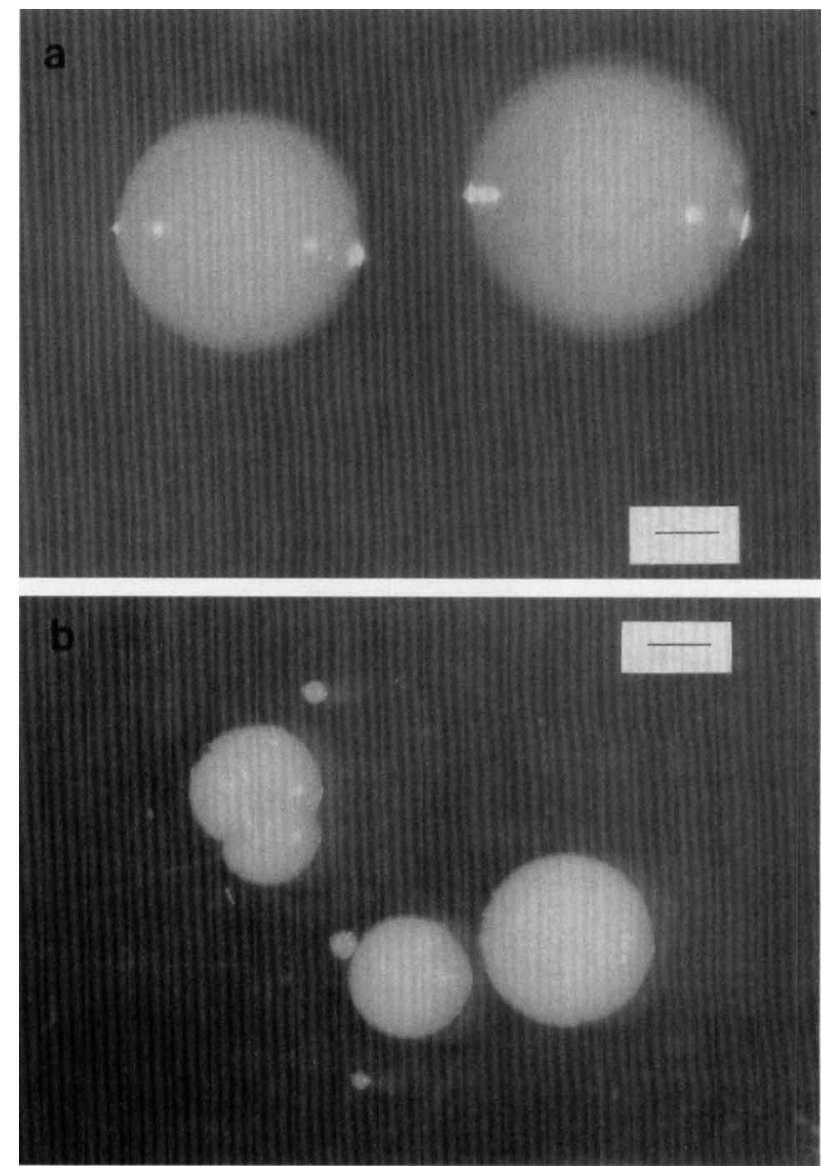

FIG. 2. (a) Single colonies of strain HKI $83^{\mathrm{T}}$ grown on solid R medium a $28^{\circ} \mathrm{C}$ for 5 days. Bar $=1 \mathrm{~mm}$. (b) Single colonies of strain HKI 84 grown on solid $\mathrm{R}$ medium at $28^{\circ} \mathrm{C}$ for 5 days. Bar $=1 \mathrm{~mm}$. 
TABLE 1. Morphological and biochemical characteristics of J. limosus HKI $83^{\mathrm{T}}$ and HKI 84

\begin{tabular}{|c|c|c|}
\hline Characteristic & Strain HKI $83^{\mathrm{T}}$ & Strain HKI 84 \\
\hline Color of colonies & White & Yellow \\
\hline Morphology & Coccoid, rod shaped & Coccoid \\
\hline Motility & $-{ }^{a}$ & - \\
\hline Gram staining & + & + \\
\hline Spore formation & - & - \\
\hline \multicolumn{3}{|l|}{ Acid production from: } \\
\hline L-Arabinose & - & - \\
\hline D-Cellobiose & - & - \\
\hline Dextrin & - & - \\
\hline D-Fructose & - & - \\
\hline D-Galactose & - & - \\
\hline D-Glucose & - & - \\
\hline Glycerol & - & - \\
\hline Inulin & - & - \\
\hline Lactose & - & - \\
\hline Maltose & - & - \\
\hline D-Mannitol & - & - \\
\hline D-Mannose & - & - \\
\hline D-Raffinose & - & - \\
\hline L-Rhamnose & - & - \\
\hline D-Ribose & - & - \\
\hline Saccharose & - & - \\
\hline Salicin & - & - \\
\hline D-Sorbitol & - & - \\
\hline Starch & - & - \\
\hline Trehalose & - & - \\
\hline D-Xylose & - & - \\
\hline \multicolumn{3}{|l|}{ Utilization of: } \\
\hline Acetate & + & - \\
\hline Aconitate & - & - \\
\hline Benzoate & - & - \\
\hline Citrate & + & + \\
\hline Formate & + & + \\
\hline Malate & + & + \\
\hline Succinate & - & - \\
\hline Hippurate & - & - \\
\hline DL-Tartrate & - & - \\
\hline \multicolumn{3}{|l|}{ Decomposition of: } \\
\hline Adenine & - & - \\
\hline Casein & + & + \\
\hline Esculin & - & - \\
\hline Gelatin & + & + \\
\hline Hypoxanthine & - & - \\
\hline Potato starch & + & + \\
\hline Tween 80 & + & + \\
\hline Tyrosine & + & + \\
\hline Urea & - & - \\
\hline Xanthine & - & - \\
\hline Nitrate reduction & + & + \\
\hline Production of $\mathrm{H}_{2} \mathrm{~S}$ & + & + \\
\hline Production of indole & - & - \\
\hline Voges-Proskauer test & - & - \\
\hline Methyl red test & - & - \\
\hline Oxidase test & + & + \\
\hline Catalase reaction & + & + \\
\hline \multicolumn{3}{|c|}{ Growth in the presence of: } \\
\hline $2 \% \mathrm{NaCl}$ & + & + \\
\hline $4 \% \mathrm{NaCl}$ & + & + \\
\hline $10 \% \mathrm{NaCl}$ & + & + \\
\hline \multicolumn{3}{|c|}{ Growth on BHI medium at: } \\
\hline $28^{\circ} \mathrm{C}$ & + & + \\
\hline $37^{\circ} \mathrm{C}$ & + & + \\
\hline \multicolumn{3}{|c|}{ Growth on $\mathrm{R}$ medium at: } \\
\hline $28^{\circ} \mathrm{C}$ & + & + \\
\hline $37^{\circ} \mathrm{C}$ & - & - \\
\hline \multicolumn{3}{|l|}{ Antibiotic susceptibility } \\
\hline Ampicillin $(10 \mu \mathrm{g})$ & + & + \\
\hline
\end{tabular}

TABLE $1-$ Continued

\begin{tabular}{lcc}
\hline \multicolumn{1}{c}{ Characteristic } & Strain HKI $83^{\mathrm{T}}$ & Strain HKI 84 \\
\hline Chloramphenicol $(30 \mu \mathrm{g})$ & + & + \\
Ciprofloxacin $(5 \mu \mathrm{g})$ & + & + \\
Erythromycin $(15 \mu \mathrm{g})$ & + & + \\
Gentamicin $(10 \mu \mathrm{g})$ & + & + \\
Kanamycin $(30 \mu \mathrm{g})$ & + & + \\
Lincomycin $(2 \mu \mathrm{g})$ & + & + \\
Neomycin $(30 \mu \mathrm{g})$ & + & + \\
Nitrofuran $(300 \mu \mathrm{g})$ & + & + \\
Oxacillin $(5 \mu \mathrm{g})$ & - & + \\
Oxytetracycline $(30 \mu \mathrm{g})$ & + & + \\
Penicillin G $(2 \mathrm{IU})$ & - & + \\
Polymyxin B $(300 \mathrm{IU})$ & + & - \\
Rifampin $(2 \mu \mathrm{g})$ & - & + \\
Streptomycin $(10 \mu \mathrm{g})$ & - & - \\
Sulfonamide $(300 \mu \mathrm{g})$ & - & \\
\hline
\end{tabular}

${ }^{a}-$, negative; + , positive

Chemotaxonomic characteristics. Diagnostic features that differentiate the new isolates from related genera are shown in Table 2 . The peptidoglycan type is A1 $\gamma$ (directly cross-linked meso-diaminopimelic acid [meso- $\left.\left.\mathrm{A}_{2} \mathrm{pm}\right]\right)$, the cell wall AlaGlu-meso- $\mathrm{A}_{2}$ pm ratio for strain $\mathrm{HKI} 83^{\mathrm{T}}$ is $1.6: 1.0: 1.1$, and mycolic acids are absent. The acyl type is acetyl, the menaquinone is $\mathrm{MK}-8\left(\mathrm{H}_{4}\right)$, and the polar lipids are diphosphatidylglycerol, phosphatidylglycerol, and phosphatidylinositol. Diagnostic cell wall sugars like arabinose and galactose are not detected, but mannose, ribose, and glucose are present. The complex fatty acid profile of strain $\mathrm{HKI} 83^{\mathrm{T}}$ is characterized by $\mathrm{C}_{17: 1}, \mathrm{C}_{17: 0}$, and $\mathrm{i}-\mathrm{C}_{16: 0}$, as well as minor amounts of straightchain saturated and unsaturated fatty acids (Table 3 ). Strain HKI 84 has a complex fatty acid profile with $\mathrm{i}-\mathrm{C}_{16: 0}$ and $\mathrm{C}_{17: 1}$ as its major components. In both strains branched-chain fatty acids other than $\mathrm{i}-\mathrm{C}_{16: 0}$ occur only in small amounts $(<3 \%)$.

DNA base composition and DNA-DNA relatedness. The DNA base composition of both strains is $70 \mathrm{~mol} \% \mathrm{G}+\mathrm{C}$. The level of DNA-DNA relatedness between strains HKI $83^{\mathrm{T}}$ and HKI 84 is $70.8 \%$.

16S rDNA sequence analysis. Almost complete $16 \mathrm{~S}$ rDNA sequences of strain $\mathrm{HKI} 83^{\mathrm{T}}$, strain $\mathrm{HKI} 84$, and $M$. multipartita JCM $9543^{\mathrm{T}}$ comprising between 1,466 and 1,473 nucleotides ( $>95 \%$ of the Escherichia coli sequence) were determined in this study. The phylogenetic dendrogram shown in Fig. 3 was constructed from evolutionary distances by the least-squares distance method (7). A total of 1,232 nucleotides present in all strains between positions 41 and 1448 (E. coli numbering) were used for this analysis. Figure 3 shows that strains HKI $83^{\mathrm{T}}$ and HKI 84 fall within the radiation of the cluster comprising the genera Intrasporangium, Terrabacter, and Sanguibacter. The levels of $16 \mathrm{~S}$ rDNA sequence similarity between organisms belonging to this cluster range from 94.8 to $97 \%$. The level of 16S rDNA sequence similarity between strains HKI $83^{\mathrm{T}}$ and HKI 84 when all 1,473 aligned nucleotide positions were compared was $99.4 \%$. The levels of $16 \mathrm{~S}$ rDNA sequence similarity to the other representatives of the actinomycetes included in the analysis and displayed in Fig. 3 ranged from 81.6 to $94.0 \%$.

\section{DISCUSSION}

In the course of an isolation program designed to obtain new actinomycetes that produce useful bioactive compounds, we studied the chemotaxonomic and physiological properties of a large number of strains obtained from quite different sources. Two of these isolates attracted our attention because of their 
TABLE 2. Differential characteristics of the genus Janibacter and other actinomycete genera ${ }^{a}$

\begin{tabular}{|c|c|c|c|c|c|c|}
\hline Genus & $\begin{array}{c}\mathrm{G}+\mathrm{C} \text { content } \\
(\mathrm{mol} \%)\end{array}$ & $\begin{array}{l}\text { Diamino acid/ } \\
\text { murein type }\end{array}$ & $\begin{array}{l}\text { Mycolic } \\
\text { acids }\end{array}$ & $\begin{array}{l}\text { Major mena- } \\
\text { quinone(s) }\end{array}$ & Polar lipids & $\begin{array}{l}\text { Cellular fatty } \\
\text { acid types }\end{array}$ \\
\hline Janibacter gen. nov. & 70 & meso- $\mathrm{A}_{2} \mathrm{pm} / \mathrm{A} 1 \gamma$ & - & MK-8 $\left(\mathbf{H}_{4}\right)$ & DPG, PG, PI & $\mathrm{S}, \mathrm{I}, \mathrm{U}$ \\
\hline Microsphaera $^{b}$ & 67.5 & $m e s o-\mathrm{A}_{2} \mathrm{pm} / \mathrm{A} 1 \gamma$ & - & MK- $8\left(\mathrm{H}_{4}\right)$ & ND & $\mathrm{S}, \mathrm{A}, \mathrm{I}, \mathrm{U}$ \\
\hline Brachybacterium $^{c}$ & $68-72$ & $m e s o-\mathrm{A}_{2} \mathrm{pm} / \mathrm{A} 4 \gamma$ & - & MK-7 & DPG, PG, GL & $\mathrm{S}, \mathrm{A}, \mathrm{I}$ \\
\hline Dermabacter ${ }^{d}$ & 62 & $m e s o-\mathrm{A}_{2} \mathrm{pm} / \mathrm{A} 1 \gamma$ & - & MK-9, MK-8 & PG, PL, GL & $\mathrm{S}, \mathrm{A}, \mathrm{I}$ \\
\hline Brevibacterium $^{e}$ & $60-67$ & meso- $\mathrm{A}_{2} \mathrm{pm} / \mathrm{A} 1 \gamma$ & - & MK- $8\left(\mathbf{H}_{2}\right)$, MK- $7\left(\mathrm{H}_{2}\right)$ & DPG, PG, GL & S, A, I \\
\hline Kineococcus ${ }^{f}$ & 75 & meso- $\mathrm{A}_{2} \mathrm{pm} / \mathrm{A} 1 \gamma$ & - & $\mathrm{MK}-9\left(\mathbf{H}_{2}\right)$ & DPG, PG, PGL & $\mathrm{S}, \mathrm{A}, \mathrm{I}$ \\
\hline Intrasporangium $^{g}$ & 68.2 & $\mathrm{LL}-\mathrm{A}_{2} \mathrm{pm} / \mathrm{A} 3 \gamma$ & - & MK-8 & DPG, PG, PI, PIM & $\mathrm{S}, \mathrm{A}, \mathrm{I}$ \\
\hline Terrabacter $^{g}$ & $70-73$ & LL- $\mathrm{A}_{2} \mathrm{pm} / \mathrm{A} 3 \gamma$ & - & MK-8 $\left(\mathrm{H}_{4}\right)$ & DPG, PI, PE, PL & $\mathrm{S}, \mathrm{A}, \mathrm{I}$ \\
\hline Nocardioides $^{g}$ & $66-72$ & $\mathrm{LL}-\mathrm{A}_{2} \mathrm{pm} / \mathrm{A} 3 \gamma$ & - & MK- $8\left(\mathbf{H}_{4}\right)$ & DPG, PG, PG-OH, PL & $\mathrm{C}$ \\
\hline Aeromicrobium $^{g}$ & $71-73$ & LL-A $\mathrm{A}_{2} \mathrm{pm} / \mathrm{A} 3 \gamma$ & - & MK-9 $\left(\mathrm{H}_{4}\right)$ & $P E, P G$ & $\mathrm{~S}, \mathrm{U}, \mathrm{T}, 2 \mathrm{OH}-\mathrm{FA}$ \\
\hline Luteococcus $^{g}$ & $66-68$ & LL-A $\mathrm{A}_{2} \mathrm{pm} / \mathrm{A} 3 \gamma$ & - & MK-9 $\left(\mathbf{H}_{4}\right)$ & DPG, PG, PI, GL & $\mathrm{S}, \mathrm{U}$ \\
\hline Microlunatus ${ }^{g}$ & 67.9 & $\mathrm{LL}-\mathrm{A}_{2} \mathrm{pm} / \mathrm{A} 3 \gamma$ & - & MK-9 $\left(\mathrm{H}_{4}\right)$ & DPG, PG, PI, PL & $\mathrm{S}, \mathrm{A}, \mathrm{I}$ \\
\hline Dermatophilus ${ }^{h}$ & $57-59$ & $m e s o-\mathrm{A}_{2} \mathrm{pm} / \mathrm{A} 1 \gamma$ & - & $\mathrm{MK}-8\left(\mathrm{H}_{4}\right)$ & DPG, PG, PI & $\mathrm{S}, \mathrm{U}$ \\
\hline Pseudonocardia ${ }^{i}$ & 79 & $m e s o-\mathrm{A}_{2} \mathrm{pm} / \mathrm{A} 1 \gamma$ & - & MK-8( $\left(\mathbf{H}_{4}\right)$ & DPG, PG, PC, PE, PI, GL & A, I \\
\hline Turicella ${ }^{j}$ & $65-72$ & meso- $\mathrm{A}_{2} \mathrm{pm}$ & - & MK-10, MK-11 & ND & $\mathrm{S}, \mathrm{U}, \mathrm{T}$ \\
\hline Rhodococcus ${ }^{k}$ & $63-73$ & $m e s o-\mathrm{A}_{2} \mathrm{pm} / \mathrm{A} 1 \gamma$ & + & $\mathrm{MK}-8\left(\mathrm{H}_{2}\right)$ & DPG, PI, PE, PIM & $\mathrm{S}, \mathrm{U}, \mathrm{T}$ \\
\hline Corynebacterium $^{k}$ & $51-67$ & $m e s o-\mathrm{A}_{2} \mathrm{pm} / \mathrm{A} 1 \gamma$ & + & MK-9( $\left.\mathrm{H}_{2}\right)$, MK- $8\left(\mathrm{H}_{2}\right)$ & DPG, PI, PIM & $\mathrm{S}, \mathrm{U}$ \\
\hline Sanguibacter & $69-70$ & L-Lys/A4 $\alpha$ & ND & MK-9 $\left(\mathbf{H}_{4}\right)$ & ND & $\mathrm{S}, \mathrm{A}, \mathrm{I}$ \\
\hline
\end{tabular}

a Abbreviations: LL-A 2 pm, LL-diaminopimelic acid; L-Lys, L-lysine; DPG, diphosphatidylglycerol; PG, phosphatidylglycerol; PE, phosphatidylethanolamine; PI, phosphatidylinositol; PIM, phosphatidylinositol mannosides; PC, phosphatidylcholine; PG-OH, phosphatidylglycerol containing 2-hydroxy fatty acids; PL, unknown phospholipid; GL, unknown glycolipid; PGL, unknown phosphoglycolipid; S, straight chain saturated; I, iso branched; A, anteiso branched; U, monounsaturated; T, tuberculostearic acid; 2OH-FA, 2-hydroxylated fatty acid; C, complex (straight chain saturated, monounsaturated, iso branched, anteiso branched, tuberculostearic acid, and 2-hydroxylated fatty acid); ND, not determined. +, present; - , absent

${ }^{b}$ Data from reference 45 .

${ }^{c}$ Data from references 3 and 15.

${ }^{d}$ Data from reference 19

${ }^{e}$ Data from reference 2 .

${ }^{f}$ Data from reference 44

${ }^{g}$ Data from reference 35

${ }^{h}$ Data from reference 36

${ }^{i}$ Data from reference 42

${ }^{j}$ Data from reference 9.

${ }^{k}$ Data from references 24 and 37.

${ }^{i}$ Data from reference 8 .

unique taxonomic characteristics. These strains were isolated only from a sludge sample that resulted from wastewater treatment. Strains of this chemotaxonomic type were not found in the other habitats examined.

A phylogenetic analysis based on a $16 \mathrm{~S}$ rDNA sequence comparison revealed that the two isolates are closely related and that their sequences are phylogenetically distinct from all actinomycete sequences available in databases. The genera Terrabacter, Intrasporangium, and Sanguibacter are the closest phylogenetic neighbors of the new isolates (Fig. 3). The genera Terrabacter and Intrasporangium differ from the new isolates in peptidoglycan type because they have type $\mathrm{A} 3 \gamma$ peptidoglycans with LL-diaminopimelic acid, a Gly ${ }_{3}$ interpeptide bridge, and a glycine residue bound to the $\alpha$-carboxyl group of D-glutamic acid in the peptide subunit $(34,35)$. Differences in the fatty acid patterns were also found, with the predominant fatty acid $\mathrm{i}-\mathrm{C}_{15: 0}$ (35) distinguishing the genera Terrabacter and Intrasporangium from the strains described here. Additional differences which characterize the genus Intrasporangium are my- celial growth and the presence of completely unsaturated menaquinone MK-8 (21). In contrast to strains HKI $83^{\mathrm{T}}$ and HKI 84, members of the genus Sanguibacter are motile and can be distinguished by the presence of major menaquinone $\mathrm{MK}$ $9\left(\mathrm{H}_{4}\right)$, by having peptidoglycan type A4 $\alpha$ with a L-Lys-Ser-DGlu interpeptide bridge, and by a fatty acid composition whose predominant components are anteiso- $C_{15: 0}$ and $C_{16: 0}(8)$.

While peptidoglycan type $\mathrm{A} 1 \gamma$ is characteristic for mycolic acid-containing genera (e.g., the genera Corynebacterium and Rhodococcus), the following six coryneform genera are known to contain meso- $\mathrm{A}_{2} \mathrm{pm}$ and to lack mycolic acids: the genera Brevibacterium (2), Brachybacterium (3, 15), Dermabacter (19), Kineococcus (44), Microsphaera (45), and Turicella (9). Members of these genera exhibit coccoid or rod-shaped morphology similar to the morphology of the strains described here. In contrast to members of the genera Brachybacterium (3), Dermabacter (19), and Kineococcus (44), members of the genus Brevibacterium (2) and new isolates HKI $83^{\mathrm{T}}$ and HKI 84 are not able to produce acid from sugars in a peptone medium.

TABLE 3. Fatty acid compositions of J. limosus HKI $83^{\mathrm{T}}$ and HKI 84

\begin{tabular}{|c|c|c|c|c|c|c|c|c|c|c|c|c|c|c|c|c|c|c|c|}
\hline \multirow{2}{*}{ Strain } & \multicolumn{19}{|c|}{ Fatty acid composition (\%) ${ }^{a}$} \\
\hline & $\mathrm{i}-\mathrm{C}_{14: 0}$ & $\mathrm{C}_{14: 0}$ & $\mathrm{i}-\mathrm{C}_{15: 0}$ & ai- $C_{15: 0}$ & $\mathrm{C}_{15: 0}$ & $\mathrm{C}_{15: 1}$ & $\mathrm{i}-\mathrm{C}_{16: 0}$ & $\mathrm{i}-\mathrm{C}_{16: 1}$ & $C_{16: 0}$ & $\mathrm{C}_{16: 1}$ & $\mathrm{i}-\mathrm{C}_{17: 0}$ & $\mathrm{i}-\mathrm{C}_{17: 1}$ & ai- $C_{17: 1}$ & $\mathrm{C}_{17: 0}$ & $\mathrm{C}_{17: 1}$ & $\mathrm{i}-\mathrm{C}_{18: 0}$ & $\mathrm{i}-\mathrm{C}_{18: 1}$ & $\mathrm{C}_{18: 0}$ & $\mathrm{C}_{18: 1}$ \\
\hline HKI $83^{\mathrm{T}}$ & 0.5 & 0.4 & 1.7 & 0.3 & 3.8 & 0.3 & 17.5 & 0 & 3.9 & 2.4 & 1.3 & 0 & 0.2 & 20.5 & 29.7 & 1.4 & 0.7 & 2.4 & 8.1 \\
\hline HKI 84 & 0.7 & 0.2 & 0.7 & 0.1 & 0.9 & 0.3 & 40.8 & 0.3 & 1.3 & 2.6 & 1.0 & 0.2 & 0.1 & 5.0 & 27.6 & 0.3 & 2.9 & 0.7 & 8.5 \\
\hline
\end{tabular}

${ }^{a}$ The abbreviations for fatty acids are illustrated by the following examples: $\mathrm{C}_{16: 0}$, hexadecanoic acid; $\mathrm{C}_{18: 1}$, octadecenoic acid; i- $\mathrm{C}_{15: 0}, 13-$ methyltetradecanoic acid; ai- $\mathrm{C}_{15: 0}, 12-$ methyltetradecanoic acid. $\mathrm{i}$, iso; ai, anteiso. 


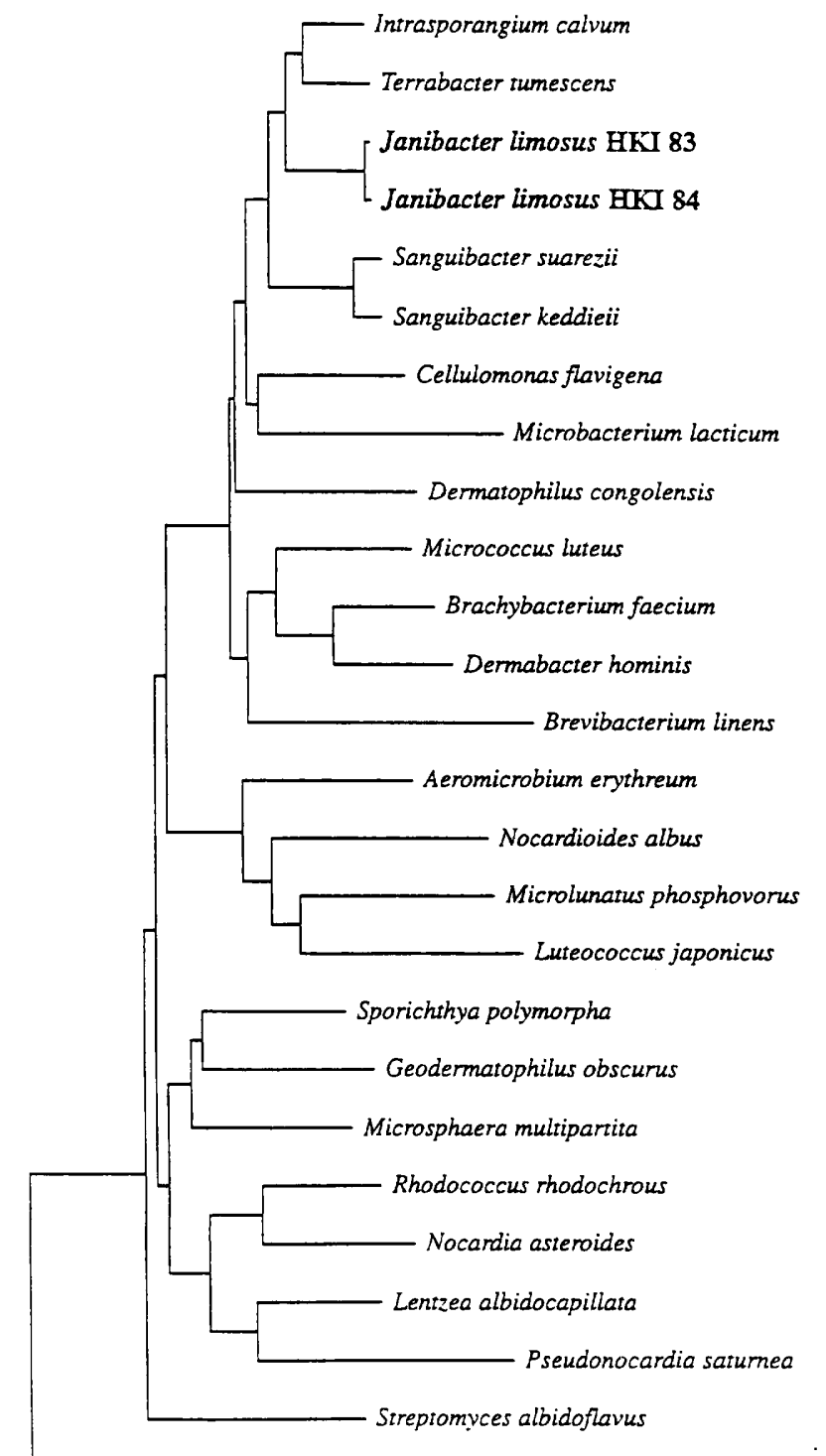

$5 \%$

FIG. 3. Phylogenetic dendrogram based on the results of a $16 \mathrm{~S}$ rDNA sequence comparison. Bar $=5$ nucleotide substitutions per 100 nucleotides.

Strains HKI $83^{\mathrm{T}}$ and HKI 84 can be easily distinguished from members of the genera Brevibacterium, Brachybacterium, Dermabacter, Kineococcus, and Turicella on the basis of the presence of menaquinone MK- $8\left(\mathrm{H}_{4}\right)$ and differences in the fatty acid profiles. Compared with strains HKI $83^{\mathrm{T}}$ and HKI 84 , members of the genera Brevibacterium and Dermabacter are characterized by lower DNA G+C contents and members of the genus Kineococcus are characterized by higher DNA G $+\mathrm{C}$ contents (Table 2). Strains HKI $83^{\mathrm{T}}$ and HKI 84 have the same peptidoglycan type, (type $\mathrm{A} 1 \gamma$ ) and the same menaquinone [menaquinone MK- $8\left(\mathrm{H}_{4}\right)$ ] as members of the genera Microsphaera, Dermatophilus, and Pseudonocardia but are phylogenetically unrelated to these taxa (Fig. 3). $M$. multipartita also differs in its predominant fatty acids (iso- $\mathrm{C}_{16: 0}$, iso- $\mathrm{C}_{15: 0}$, and $\left.\mathrm{C}_{18: 1}\right)$ and in having a lower $\mathrm{G}+\mathrm{C}$ content $(67.5 \mathrm{~mol} \%)$. Representatives of the genus Dermatophilus are characterized by the formation of mycelia and by low $\mathrm{G}+\mathrm{C}$ contents $(57$ to 59 mol\%) compared with strains HKI $83^{\mathrm{T}}$ and HKI 84 (36).

The genus Pseudonocardia is characterized by the presence of arabinose and galactose as diagnostic cell wall sugars; these sugars could not be detected in our isolates. The polar lipids phosphatidylcholine and phosphatidylethanolamine, which are present in members of the genus Pseudonocardia, were not found in strains HKI $83^{\mathrm{T}}$ and HKI 84 (42).

On the basis of the results of our $16 \mathrm{~S}$ rDNA sequence analysis and chemotaxonomic comparisons, we propose that the new genus Janibacter should be established for the strains described in this study. The type species of the genus Janibacter is Janibacter limosus sp. nov., which is represented by type strain HKI 83 and strain HKI 84.

Description of Janibacter gen. nov. Janibacter (Ja.ni.bac'ter. L. n. Janus, a god in roman mythology, who is said to have had two faces; M. L. masc. n. bacter, a rod; L. n. Janibacter, referring to the changing morphology of the microorganisms). Cells are gram positive, coccoid to rod shaped, and nonmotile and occur singly, in pairs, or occasionally in irregular clumps. No spores are formed. Not acid fast. Aerobic chemoorganotroph. Catalase is produced. Oxidase negative. The habitat of the strains is sludge and sewage waste. The cell wall type is A1 $\gamma$ (directly cross-linked meso- $\mathrm{A}_{2} \mathrm{pm}$ ). Mycolic acids are absent; the menaquinone is MK- $8\left(\mathrm{H}_{4}\right)$. The fatty acid profile is complex with straight-chain saturated and monounsaturated fatty acids as the major components, and the polar lipids are diphosphatidylglycerol, phosphatidylglycerol, and phosphatidylinositol. The DNA base composition is $70 \mathrm{~mol} \% \mathrm{G}+\mathrm{C}$. The type species is Janibacter limosus.

Description of Janibacter limosus sp. nov. Janibacter limosus (li.mo'sus. L. adj. limosus, muddy, pertaining to sludge, the natural habitat of the species). Cells are gram-positive and nonmotile and occur singly, in pairs, or occasionally in irregular clumps. In liquid cultures cells are coccoid (diameter, 0.3 to $1.2 \mu \mathrm{m}$ ). On solid medium strains vary in cell morphology. The cells of some strains are short rods $(0.4$ by $1.4 \mu \mathrm{m})$, which change shape and become coccoid in older cultures. Colonies on nutrient agar are white or yellow, opaque, and convex; the colony surfaces are glistening or matt; and the colony margins are entire. J. limosus grows aerobically and tolerates $4 \%$ (wt/ vol) $\mathrm{NaCl}$ in the medium. The optimal growth temperature is $28^{\circ} \mathrm{C}$; growth occurs at $37^{\circ} \mathrm{C}$ on $\mathrm{BHI}$ medium but not on $\mathrm{R}$ medium. No growth occurs under anaerobic conditions. Catalase, indole, and $\mathrm{H}_{2} \mathrm{~S}$ are produced; urease and oxidase are not produced. Gelatin, starch, Tween 80 , and casein are hydrolyzed. Citrate, formate, malate, and tyrosine are decomposed; aconitate, benzoate, succinate, tartrate, hippurate, esculin, adenine, xanthine, and hypoxanthine not decomposed. Nitrate is reduced to nitrite. Voges-Proskauer and methyl red reactions are negative. No acid is produced from $\mathrm{L}$-arabinose, cellobiose, dextrin, fructose, galactose, glucose, glycerol, $m$-inositol, inulin, lactose, maltose, mannitol, mannose, raffinose, L-rhamnose, ribose, salicin, D-sorbitol, sucrose, potato starch, trehalose, and D-xylose. Has the chemotaxonomic characteristics of the genus. The DNA base composition is $70 \mathrm{~mol} \% \mathrm{G}+\mathrm{C}$. The type strain is strain HKI 83 (= DSM 11140).

\section{ACKNOWLEDGMENTS}

We thank Christiane Weigel, Carmen Schult, Karin Hößrich, and Renate Schumann for excellent technical assistance. Jutta Burghardt is thanked for carrying out DNA-DNA reassociation experiments.

This work was supported by grant $0310591 \mathrm{~A}$ from the Bundesministerium für Bildung, Wissenschaft, Forschung und Technologie, Germany. 


\section{REFERENCES}

1. Cashion, P., M. A. Holder-Franklin, J. McCully, and M. Franklin. 1977. A rapid method for the base ratio determination of bacterial DNA. Anal. Biochem. 81:461-466.

2. Collins, M. D. 1992. The genus Brevibacterium, p. 1351-1354. In A. Balows, H. G. Trüper, M. Dworkin, W. Harder, and K. H. Schleifer (ed.), The prokaryotes, 2nd ed. Springer-Verlag, New York, N.Y.

3. Collins, M. D., J. Brown, and D. Jones. 1988. Brachybacterium faecium gen. nov., sp. nov., a coryneform bacterium from poultry deep litter. Int. J. Syst. Bacteriol. 38:45-48.

4. Collins, M. D., T. Pirouz, M. Goodfellow, and D. E. Minnikin. 1977. Distribution of menaquinones in actinomycetes and corynebacteria. J. Gen. Microbiol. 100:221-230.

5. Cowan, S. T., and K. J. Steel. 1965. Manual for the identification of medical bacteria. Cambridge University Press, Cambridge, United Kingdom.

6. De Ley, J., H. Cattoir, and A. Reynaerts. 1970. The quantitative measurement of DNA hybridization from renaturation rates. Eur. J. Biochem. 12: 133-142.

7. De Soete, G. 1983. A least squares algorithm for fitting additive trees to proximity data. Psychometrika 48:621-626.

8. Fernandez-Garayzabal, J. F., L. Dominguez, C. Pascual, D. Jones, and M. Collins. 1995. Phenotypic and phylogenetic characterization of some unknown coryneform bacteria isolated from bovine blood and milk: description of Sanguibacter gen. nov. Lett. Appl. Microbiol. 20:69-75.

9. Funke, G., S. Stubbs, M. Altwegg, A. Carlotti, and M. D. Collins. 1994 Turicella otidis gen. nov, sp. nov., a coryneform bacterium isolated from patients with otidis media. Int. J. Syst. Bacteriol. 44:270-273.

10. Gledhill, W. E., and L. E. Casida, Jr. 1969. Predominant catalase-negative soil bacteria. III. Agromyces, gen. n., microorganisms intermediary to Actinomyces and Nocardia. Appl. Microbiol. 18:340-349.

11. Gordon, R. E., D. A. Barnett, J. E. Handerhan, and C. H.-N. Pang. 1974 Nocardia coeliaca, Nocardia autotrophica, and the nocardin strain. Int. J. Syst. Bacteriol. 24:54-63.

12. Gordon, R. E., and J. M. Mihm. 1957. A comparative study of some strains received as nocardiae. J. Bacteriol. 73:15-27.

13. Gräfe, U., M. Ritzau, W. Ihn, U. Möllmann, W. F. Fleck, I. Groth, and R. Reissbrodt. 1994. A new microbial isoquinoline iron chelator from Streptomyces spec. 2002-104. J. Basic Microbiol. 34:351-355.

14. Groth, I., P. Schumann, N. Weiss, K. Martin, and F. Rainey. 1996. Agrococcus jenensis gen. nov., sp. nov., a new genus of actinomycetes with diaminobutyric acid in the cell wall. Int. J. Syst. Bacteriol. 46:234-239.

15. Gvozdyak, O. R., T. M. Nogina, and P. Schumann. 1992. Taxonomic study of the genus Brachybacterium: Brachybacterium nesterenkovii sp. nov. Int. J. Syst. Bacteriol. 42:74-78

16. Hugh, R., and E. Leifson. 1953. The taxonomic significance of fermentative versus oxidative metabolism of carbohydrates by various Gram negative bacteria. J. Bacteriol. 66:24-26.

17. Huss, V. A. R., H. Festl, and K. H. Schleifer. 1983. Studies on the spectrophotometric determination of DNA hybridization from renaturation rates. Syst. Appl. Microbiol. 4:184-192.

18. Janke, K.-D. 1992. BASIC computer program for evaluation of spectroscopic DNA renaturation data from GILFORD SYSTEM 2600 spectrophotometer on a PC/XT/AT type personal computer. J. Microbiol. Methods 15:61-73.

19. Jones, D., and M. D. Collins. 1988. Taxonomic studies on some human cutaneous coryneform bacteria: description of Dermabacter hominis gen. nov., sp. nov. FEMS Microbiol. Lett. 51:51-56

20. Jukes, T. H., and C. R. Cantor. 1969. Evolution of protein molecules, p. 21-132. In H. N. Munro (ed.), Mammalian protein metabolism. Academic Press, New York, N.Y

21. Kalakoutskii, L. V. 1989. Genus Intrasporangium Kalakoutskii, Kirillova and Krasil'nikov 1967, 79AL, p. 2395-2397. In S. T. Williams, M. E. Sharpe, and J. G. Holt (ed.), Bergey's manual of systematic bacteriology, vol. 4. The Williams and Wilkins Co., Baltimore, Md.

22. Kästner, M., M. Breuer-Jammali, and B. Mahro. 1994. Enumeration and characterization of the soil microflora from hydrocarbon-contaminated soil sites able to mineralize polycyclic aromatic hydrocarbons (PAH). Appl. Microbiol. Biotechnol. 41:267-273.

23. Kramer, R. 1996. Genetic and physiological approaches for the production of amino acids. J. Biotechnol. 45:1-21.

24. Kroppenstedt, R. M. 1985. Fatty acids and menaquinone analysis of actinomycetes and related organisms, p. 173-189. In M. Goodfellow and D. E.
Minnikin (ed.), Chemical methods in bacterial systematics. Academic Press, London, United Kingdom.

25. Lanyi, B. 1987. Classical and rapid identification methods for medically important bacteria. Methods Microbiol. 19:1-67.

26. Maisnierpatin, S., and J. Richard. 1995. Activity and purification of linenscin $\mathrm{OC} 2$, an antibacterial substance produced by Brevibacterium linens $\mathrm{OC} 2$, an orange cheese coryneform bacterium. Appl. Environ. Microbiol. 61:18471852.

27. Marmur, J. 1961. A procedure for the isolation of deoxyribonucleic acid from microorganisms. J. Mol. Biol. 3:208-218.

28. Mesbah, M., U. Premachandran, and W. B. Whitman. 1989. Precise measurement of the $\mathrm{G}+\mathrm{C}$ content of deoxyribonucleic acid by high-performance liquid chromatography. Int. J. Syst. Bacteriol. 39:159-167.

29. Miller, E. S., C. R. Woese, and S. Brenner. 1991. Description of the erythromycin-producing bacterium Arthrobacter sp. strain NRRL B-3381 as Aeromicrobium erythreum gen. nov., sp. nov. Int. J. Syst. Bacteriol. 41:363368

30. Minnikin, D. E., L. Alshamaony, and M. Goodfellow. 1975. Differentiation of Mycobacterium, Nocardia, and related taxa by thin-layer chromatographic analysis of whole-organism methanolysates. J. Gen. Microbiol. 88:200-204.

31. Minnikin, D. E., M. D. Collins, and M. Goodfellow, 1979. Fatty acid and polar lipid composition in the classification of Cellulomonas, Oerskovia and related taxa. J. Appl. Bacteriol. 47:87-95.

32. Rainey, F. A., N. Ward-Rainey, R. M. Kroppenstedt, and E. Stackebrandt. 1996. The genus Nocardiopsis represents a phylogenetically coherent taxon and a distinct actinomycete lineage: proposal of Nocardiopsiaceae fam. nov. Int. J. Syst. Bacteriol. 46:1088-1092.

33. Saddler, G. S., P. Tavecchia, S. Lociuro, M. Zanol, L. Colombo, and E. Selva. 1991. Analysis of madurose and other actinomycete whole cell sugars by gas chromatography. J. Microbiol. Methods 14:185-191.

34. Schleifer, K. H., and O. Kandler. 1972. Peptidoglycan types of bacterial cell walls and their taxonomic implications. Bacteriol. Rev. 36:407-477.

35. Schumann, P., H. Prauser, F. A. Rainey, E. Stackebrandt, and P. Hirsch 1997. Friedmanniella antarctica gen. nov., sp. nov., an LL-diaminopimelic acid-containing actinomycete from Antarctic sandstone. Int. J. Syst. Bacteriol. 47:278-283.

36. Stackebrandt, E., R. M. Kroppenstedt, and V. J. Fowler. 1983. A phylogenetic analysis of the family Dermatophilaceae. J. Gen. Microbiol. 129:18311838

37. Stackebrandt, E., J. Smida, and M. D. Collins. 1988. Evidence of phylogenetic heterogeneity within the genus Rhodococcus: revival of the genus Gordona (Tsukamura). J. Gen. Appl. Microbiol. 34:341-348.

38. Stead, D. E., J. E. Sellwood, J. Wilson, and I. Viney. 1992. Evaluation of a commercial microbial identification system based on fatty acid profiles for rapid, accurate identification of plant pathogenic bacteria. J. Appl. Bacteriol 72:315-321

39. Suzuki, K., K. Nagai, Y. Shimizu, and Y. Suzuki. 1994. Search for actinomycetes in screening for new bioactive compounds. Actinomycetologica 8:122-127.

40. Tamaoka, J., and K. Komagata. 1984. Determination of DNA base composition by reversed-phase high-performance liquid chromatography. FEMS Microbiol. Lett. 25:125-128.

41. Uchida, K., and K. Aida. 1984. An improved method for the glycolate test for simple identification of the acyl type of bacterial cell walls. J. Gen. Appl. Microbiol. 29:131-134.

42. Warwick, S., T. Bowen, H. McVeigh, and T. M. Embley. 1994. A phylogenetic analysis of the family Pseudonocardiaceae and the genera Actinokineospora and Saccharothrix with 16S rRNA sequences and a proposal to combine the genera Amycolata and Pseudoamycolata in an emended genus Pseudonocardia. Int. J. Syst. Bacteriol. 44:293-299.

43. Yamada, K., and K. Komagata. 1972. Taxonomic studies on coryneform bacteria. IV. Morphological, cultural, biochemical, and physiological characteristics. J. Gen. Appl. Microbiol. 18:399-416.

44. Yokota, A., T. Tamura, T. Nishi, and T. Hasegawa. 1993. Kineococcus aurantiacus gen. nov., sp. nov., a new gram-positive motile coccus with mesodiaminopimelic acid and arabinogalactan in the cell wall. Int. J. Syst. Bacteriol. 43:52-57.

45. Yoshimi, Y., A. Hiraishi, and K. Nakamura. 1996. Isolation and characterization of Microsphaera multipartita gen. nov., sp. nov., a polysaccharideaccumulating gram-positive bacterium from activated sludge. Int. J. Syst. Bacteriol. 46:519-525. 